\title{
Margaret McCartney: Direct to consumer genetic testing-is all knowledge power?
}

\author{
Margaret McCartney general practitioner, Glasgow
}

"Knowledge is power," says the personal genomics company 23 andMe. ${ }^{1}$ For $£ 125$ the company offers genetic testing to the UK public, as well as a report on "over 100 health conditions and traits."

Its website predicts that you will be "excited about providing your sample" of saliva. The company's founder has stated that "everyone has the right to access and understand their genetic information ... imagine if someone told you that you couldn't look in a mirror."

Healthcare data are measured in mountains, however, and can lead to inaccurate ${ }^{3}$ or unsafe ${ }^{4}$ conclusions. The information offered by this direct to consumer testing is advertised as a way to "better manage your health and wellness." In reality it's a massive data dump of genetic variants for traits, minimal risk factors, and conditions, from familial Mediterranean fever to "breast morphology" and "norovirus resistance."

We know that patients overestimate the benefits of medical interventions and underestimate their harms. ${ }^{5} \mathrm{We}$ should expect an explanation of false positives, false negatives, and limitations of usefulness-because real power is not simply about information but about understanding caveats, reliability, and hazards of results, and understanding not only statistical but also clinical significance.

If you test positive for the genotype associated with norovirus resistance, 23andMe says, "It is important to note that not having this variant does not make someone completely resistant." So what use is it? Should this test change how we manage it? Can it ever be good advice to wash our hands less? What should we do with the knowledge that we have factor V Leiden deficiency, given that no treatment is required? Even when prescribing oral contraceptives it is likely to create many unforeseen dilemmas. ${ }^{6}$

A video on 23andMe's website describes a patient with symptoms having genetic screening for predisposition to coeliac disease before it was finally diagnosed. This is back to front medicine; clearly, diagnostic tests would have been more appropriate first.

In 2013 the US Food and Drug Administration stopped 23andMe from offering health reports because it was "concerned about the public health consequences of inaccurate results," particularly regarding the BRCA gene. ${ }^{7}$ Indeed; and the advice about how to lower your risk (exercise, be trim, do work that you enjoy, eat a Mediterranean diet, don't be poor) still stands, whatever the results.

The claim that this is all about democratised information holds only if the information does more good than harm. When for-profit companies offer screening without evidence of benefit and without individual shared decision making, insurance should be built in to protect the NHS from having to deal with the fallout.

23andMe has been funded by, among others, Google, the Roche Venture Fund, and Johnson and Johnson Innovation. ${ }^{89} 23$ andMe says that it "may share anonymised and aggregate information with third parties." Are we sure that we know what we are buying into?

Competing interests: I have read and understood the BMJ policy on declaration of interests and declare the following interests: I'm an NHS GP partner, with income partly dependent on Quality and Outcomes Framework points. I'm a part time undergraduate tutor at the University of Glasgow. I've written two books and earn from broadcast and written freelance journalism. I'm an unpaid patron of Healthwatch. I make a monthly donation to Keep Our NHS Public. I'm a member of Medact. I'm occasionally paid for time, travel, and accommodation to give talks or have locum fees paid to allow me to give talks but never for any drug or public relations company. I was elected to the national council of the Royal College of General Practitioners in 2013 and am chair of its standing group on overdiagnosis. I have invested a small amount of money in a social enterprise, Who Made Your Pants?

The BMSs readers can buy Margaret's new book, Living with Dying, for $£ 7.99$ (RRP £11.99) including UK delivery from www.pinterandmartin. com with checkout code BMJ799.

Provenance and peer review: Commissioned; not externally peer reviewed.

23andMe website. https://store.23andme.com/en-gb/cart/.

2 Wojcicki A. The future of genetics in our everyday lives-SXSW Interactive 2014. www. youtube.com/watch?v=Nr2CHwNyvNI.

Kmietowicz Z. Regulator apologises to 60 general practices for wrongly prioritising them for inspection. BMJ 2014;349:97564. 
4 Walker K, Neuburger J, Groene O, Cromwell DA, van der Meulen J. Public reporting of surgeon outcomes: low numbers of procedures lead to false complacency. Lancet 2013;382:1674-7.

5 Hoffmann TC, Del Mar C. Patients' expectations of the benefits and harms of treatments, screening, and tests: a systematic review. JAMA Intern Med 2014; published online 22 Dec; doi:10.1001/jamainternmed.2014.6016.

6 van Vlijmen EFW, Veeger NJGM, Middeldorp S, Hamulyak K, Prins MH, Buller HR, et al. Thrombotic risk during oral contraceptive use and pregnancy in women with factor $\mathrm{V}$ Leiden or prothrombin mutation: a rational approach to contraception. Blood 2011;118:2055-61.
7 Food and Drug Administration. Inspections, compliance, enforcement, and criminal investigations. www.fda.gov//CECl/

8 23andMe. Corporate info. www.23andme.com/en-gb/about/corporate/.

9 Johnson and Johnson Innovation website. www.jjdevcorp.com/.

Cite this as: BMJ 2015;350:h439

(c) BMJ Publishing Group Ltd 2015 